\title{
Využití systému Galileo ve stavebním inženýrství
}

\author{
Leoš Mervart \\ Department of Advanced Geodesy \\ Faculty of Civil Engineering, CTU in Prague \\ E-mail: mervart@fsv.cvut.cz
}

Klíčová slova: Systém Galileo, stavební inženýrství, výzkumný plán MSM 6840770032

\section{Popis výzkumného záměru}

\section{Předmět a cíl výzkumného záměru}

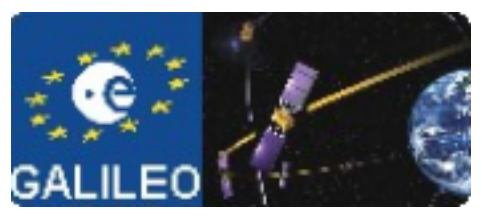

Vývoj prvních družicových navigačních systémů - známých též jako globální polohové systémy (GPS) - se datuje do 60. let dvacátého století. Jejich význam pro technickou praxi začal vzrůstat s postupným dokončováním systému NAVSTAR (Navigation Satellite Timing And Ranging) GPS v průběhu let 80. Od té doby se neustále zvyšuje počet aplikací a GPS se staly nepostradatelné v nejrůznějších oblastech lidské činnosti. S vývojem nových aplikací GPS se však zároveň začala projevovat určitá omezení v současné době jediného plně operačního systému NAVSTAR GPS, která jsou způsobena hlavně tím, že systém byl původně navržen pro potřeby armády Spojených států a jeho tvưrci nepočítali se stovkami různých civilních aplikací.

Z tohoto důvodu se jednou z priorit států Evropské unie stalo vybudování vlastního družicového navigačního systému, který by byl (na rozdíl od systému Spojených států) primárně navržen pro celou řadu velmi rozmanitých civilních aplikací. V průběhu složité a dlouhé přípravné fáze projektu se měnila jak jeho celková koncepce tak i název vlastního navigačního systému. Obtížná byla i jednání mezi Evropskou unií a Spojenými státy, která měla zajistit tzv. interoperabilitu stávajícího a nového navigačního systému. V současné době je možno konstatovat, že neexistují žádné další politické překážky bránící vybudování evropského navigačního systému a byla schválena i jeho detailní koncepce. V roce 2006 přešel projekt z tzv. vývojové fáze do fáze zaváděcí. Operační fáze by mělo být dosaženo v roce 2008. Navigační systém Evropské unie je založen na dvou projektech:

\section{Projektu EGNOS (Euro Geostationary Navigation Overlay Service).}

Jde o společný projekt Evropské kosmické agentury (ESA) a Evropské komise, který se bude (podle plánu z roku 2005) sestávat ze tří geostacionárních družic.

\section{Projektu GALILEO.}

Systém GALILEO (jde opět o společný projekt ESA a Evropské komise) je velmi ambiciózním projektem, který by po svém dokončení měl představovat nejmodernější technologii pro přesné určování polohy. Od 1. července 2003 do konce roku 2005 byl projekt v tzv. vývojové fázi, rokem 2006 byla zahájena tzv. zaváděcí fáze a od roku 2008 má být systém již plně funkční. V systému se počítá s celkem 30 družicemi na třech oběžných drahách (sklon k rovníku 56 stupňů, vzdálenost od Země 23616 km). Protože v roce 2004 (26. června) byla podepsána 
dohoda mezi USA a Evropskou unií "o podpoře, rozmístování a používání družicových navigačních systémů GALILEO a NAVSTAR GPS “, otevřela se cesta k uživatelské interoperabilitě a radiofrekvenční kompatibilitě obou systémů.

Systém GALILEO má v současné době jednu z nejvyšších priorit ve všech členských zemích EU. Usnesení vlády ČR číslo 218 z 23.2.2005 k organizačnímu zajištění aktivní participace České republiky na programu Galileo deklaruje připravenost České republiky k podpoře vlastních podnikatelských a výzkumných subjektů.

Návrh služeb a signálů systému GALILEO podléhal dlouhé diskusi a mnoha změnám. V současné době je však zřejmé, že jeden ze signálů systému GALILEO bude ve vysokofrekvenčním pásmu L1. Tato skutečnost otevírá cestu k jednoduchým a levným přijímačům schopným pracovat s oběma systémy - NAVSTAR GPS i GALILEO. Zároveň tím otevírá i cestu k výraznému zvýšení přesnosti a zejména spolehlivosti určování polohy při využití kombinace měření obou navigačních systémů. A jako přímý důsledek tohoto kvalitativního skoku lze očekávat ohromný rozvoj nových aplikací včetně aplikací ve stavebním inženýrství.

Domníváme se, že vzhledem k výše uvedeným skutečnostem je nezbytné soustředit úsilí vědeckých pracovníků Fakulty stavební ČVUT na výzkum a vývoj aplikací systému Galileo v oblastech geoinformatiky, krajinného a stavebního inženýrství. Jsme přesvědčeni, že pro projekt takovéhoto výzkumu máme $\mathrm{k}$ dispozici kvalitní řešitelský tým sestávající z odborníků z oblasti družicových navigačních systémů, informatiky, geodézie, dopravního stavitelství, stavebních konstrukcí a dalších stavebních oborů. Rovněž jsme přesvědčeni, že předkládaný projekt je správně věcně zacílen, že je správně načasován (vzhledem $\mathrm{k}$ budování systému GALILEO), a že jeho realizace přinese i podstatné hospodár̆ské výsledky.

Zamýšlený výzkumný záměr sestává ze tří na sebe navazujících částí:

1. Výzkum a vývoj metod pro zpracování signálů družic Galileo, problematika kombinování měření systému Galileo se stávajícím globálním polohovým systémem NAVSTAR GPS, specifika použití systému Galileo v České republice a návaznost na současné geodetické základy České republiky.

2. Výzkum a vývoj metod efektivního zpracování polohových informací poskytnutých systémem Galileo, jejich vizualizace, tvorba databázových a informačních systémů (GIS) založených na údajích poskytnutých systémem Galileo.

3. Výzkum a vývoj aplikací systému Galileo v jednotlivých oborech stavebního inženýrství.

- monitorování deformací mostních objektů

- sledování posunů stavebních objektů pomocí kombinace měření systému Galileo a metody laserového skenování

- řízení stavebních strojů

- dlouhodobé sledování posunů tramvajových a železničních tratí

- prevence rizik při dopravě nebezpečných nákladů 
- hledání a vývoj nových aplikací družicových navigačních systému ve stavebnictví

- hledání a vývoj nových aplikací družicových navigačních systémů a metod dálkového průzkumu Země ve vodním hospodářství

Jedním z hlavních cílů předkládaného výzkumného záměru je tedy komplexní vývoj stavebních aplikací systému Galileo. Pod "stavebními aplikacemi" rozumíme nejrůznější technologické postupy, jejichž součástí je získávání polohových informací o stavebních objektech, ř́zení stavebních strojů, optimalizace logistických problémů při procesu výstavby atd. Na jedné straně půjde o aplikace, které jsou v současné době řešeny jinými technologiemi (např. terestrickými měřeními). V těchto případech bude cílem vyvinout technologické postupy založené na systému Galileo, které jsou ekonomicky výhodnější, přesnější či méně rizikové pro pracovníky provádějící měření. Na straně druhé kvalitativní skok v přesnosti a spolehlivosti určení polohy, který systém Galileo přináší, otevře cestu i ke zcela novým aplikacím a technologiím, které dosavadními prostředky nebylo možno zajistit. Tyto aplikace nelze konkrétně předvídat, a proto ani vyjmenovat v návrhu výzkumného záměru, domníváme se však, že právě jejich hledání a vývoj by měly představovat významnou část navrhovaného výzkumného záměru.

Předkládaný projekt však není zaměřen pouze na aplikační úroveň systému Galileo. Projekt je předkládán pracovníky Fakulty stavební ČVUT, Mezi předkladateli projektu jsou ve značném počtu zastoupeni geodeti a kartografové (Geodézie a kartografie je jedním s oborů studovaných na stavební fakultě). Neméně důležitým cílem projektu je proto vývoj algoritmů, metod a softwarových aplikací pro zpracování původních měření systému Galileo a začlenění výsledků získaných pomocí tohoto systému do informačních systémů. Teprve na výsledky tohoto vývoje mohou navazovat jednotlivé aplikace ve stavebním a krajinném inženýrství.

Projekt je tedy určitou syntézou výzkumu v oblasti družicové geodézie a geoinformatiky s konkrétními aplikacemi ve stavebním a krajinném inženýrství.

\section{Současný stav výzkumné činnosti a úrovně poznání v oblasti, která je předmětem výzkumného záměru, z mezinárodního a národního hlediska}

Z části pojednávající o předmětu a cíli výzkumného záměru je zřejmé, že pro dosažení cílů projektu jsou nezbytné poznatky z více vědních a technických disciplín. Zde je stručné shrnutí stavu výzkumné činnosti a úrovně poznání v oborech, které jsou pro řešení záměru nejdůležitější:

\section{Družicová geodézie a navigace}

Družicová geodézie, teorie globálních polohových systémů a vývoj algoritmů a softwarových nástrojů pro zpracování družicových měření je jakýmsi "výchozím bodem" předkládaného projektu, nebot družicová měření představují prvotní zdroj dat, na nichž jsou zamýšlené aplikace založeny. Samotná družicová geodézie nemůže existovat bez vazby na další specializace spadající do oboru tzv. vyšší (teoretické) geodézie. Jejich společným úkolem je umožnit určení polohy statických či pohybujících se objektů v přesně definovaném souradnicovém a časovém systému. Protože každé určení polohy je založeno na měřeních vykonávaných v konkrétním 
fyzikálním prostředí, stává se součástí vyšší geodézie i studium fyzikálních vlastností tělesa Země a studium změn těchto vlastností v čase.

Problematice družicové navigace se pracovníci Katedry vyšší geodézie Fakulty stavební ČVUT věnují od počátku 90. let. Vedoucí katedry, prof. Mervart, je spoluautorem dvou významných softwarových systémů pro zpracování měření NAVSTAR GPS - tzv. Bernského GPS Softwaru (ve spolupráci s Astronomickým ústavem Univerzity Bern) a programu RTNET (Real-Time Network) užívaného Japonským geografickým institutem pro monitorování japonské sítě Geonet (sít cca 1200 permanentních stanic GPS) .

Prof. Mervart a Ing. Lukeš jsou autory či spoluautory mnoha vědeckých publikací s tématickou globálních polohových systémů.

Další členové řešitelského týmu - prof. Kostelecký, Ing. Vondrák, DrSc. a Ing. Pešek jsou odborníky v oboru geodetických polohových základů, geodetické astronomie a sourradnicových a časových referenčních systémů. Problematika referenčních rámců je důležitou součástí řešení, nebot’ jednotlivé navigační systémy mohou pracovat $\mathrm{v}$ různě definovaných a realizovaných referenčních rámcích, jejichž korektní transformace a následný převod výsledků do systémů užívaných v České republice je nutnou podmínkou použití družicových navigačních systémů pro přesné aplikace $\mathrm{v}$ technické praxi.

Vědecká činnost v oblasti družicové geodézie není myslitelná bez široké mezinárodní spolupráce. Výše uvedení členové řešitelského týmu jsou zapojeni do mezinárodní spolupráce $\mathrm{v}$ rámci bilaterálních smluv s našimi zahraničními partnery (zejména Astronomickým ústavem Univerzity v Bernu) a v rámci mezinárodních vědeckých organizací - zejména Mezinárodní GNSS služby (International GNSS Service) a Mezinárodní služby rotace Země a referenčních systémů (International Earth Rotation and Reference systems Service - IERS).

Z vědeckých pracovišt v České republice je naším partnerem zejména Výzkumný ústav geodetický, topografický a kartografický.

Informatika, geoinformatika, digitální kartografie a geografické informační systémy

Druhým pilî̌rem zamýšleného výzkumného záměru je skupina vědních disciplín, které by (pokud je chceme shrnout pod jednoslovným termínem) bylo možno nazvat "geoinformatikou". Tato moderní vědní disciplína aplikuje poznatky informatiky - vědy o zpracování a manipulaci s informacemi - na potřeby geodézie, kartografie a dalších vědních a technických disciplín zabývajících se měřením, zobrazováním nebo (jako v případě stavebnictví) i přetvářením zemského povrchu. V našem pojetí chápeme geoinformatiku jako velmi široký pojem, který do jisté míry zastřešuje kartografii, fotogrammetrii, dálkový průzkum Země, mapování a katastr nemovitostí. O významu geoinformatiky svědčí i skutečnost, že "Geoinformatika " je i názvem a náplní nově akreditovaného studijního oboru na Fakultě stavební ČVUT, jehož výuka bude zahájena v akademickém roce 2006/2007.

Katedra mapování a kartografie Fakulty stavební ČVUT je špičkovým pracovištěm v oborech spadajících do geoinformatiky. Součástí katedry je Laboratoř dálkového průzkumu Země, která se svým výzkumem zaměřuje na několik oblastí. Jednou z nich je sledování časových změn v krajině, které je možno určovat z dat dálkového průzkumu Země - družicových dat (optická i radarová data) i leteckých dat (letecké měřické snímky). V procesu vyhodnocování snímků je nezbytná př̀sná lokalizace sledovaných změn. Systém Galileo a jím poskytovaná 
data umožní získávání dat s podstatně větší polohovou přesností a snazší využití získaných poznatků pro praxi.

Laboratoř dálkového průzkumu Země se již několik let zabývá problematikou diferenciální interferometrie. Tato metoda umožňuje získávat informace o změnách v poloze území na zemském povrchu. Podpůrným nástrojem pro posouzení výsledku zpracováni diferenciální interferometrie je např. použití GIS, kde je na základě různého druhu vstupních dat zkoumána teoretická možnost existence poklesových oblastí. Tímto způsobem již byly porovnávány hodnoty dat přebírané z geologických, důlních aj. podkladů, které však nelze používat jako zcela spolehlivé pro potvrzení nebo vyloučení poklesů. Systém Galileo umožní sledovat polohu ve vybraných lokalitách průběžně v řádu několika let. Tato měření budou porovnávána s výsledky interferometrických vyhodnocení. Předpokladem je tedy měření systémem Galileo na předem vybraných lokalitách. Tato data budou pravidelně vyhodnocována, informace vkládána do GIS.

Další součást Katedry mapování a kartografie FSv ČVUT je Laboratoř fotogrammetrie. Činnost laboratoře se v posledních pěti letech soustředila zejména na využití pozemní fotogrammetrie v oblasti dokumentace památkových objektů, kde bylo dosaženo řady významných úspěchů i v mezinárodních projektech. Vyšší formy vyhodnocovacích systémů digitální fotogrammetrie využívají principů virtuální reality a jsou zastoupeny v laboratoři na čtyřech stanicích. Nosným projektem laboratoře z dlouhodobého hlediska je práce se systémem PhotoPa, který představuje dnes již poměrně rozsáhlou fotogrammetricko-měřickou databázi drobných památkových objektů. Sběr těchto dat má geoinformační prvky, pro lokalizaci objektů se předpokládá využití evropského navigačního systému GALILEO.

\section{Inženýrská geodézie}

Inženýrské geodézie je aplikací geodetických metod v průmyslu a stavebnictví. Mezi hlavní úkoly inženýrské geodézie patří kompletní geodetické zajištění staveb - od prací při projektové části výstavby přes vytyčení stavby až po dokumentaci jejího skutečného provedení a v některých případech i dlouhodobé sledování jejích posunů a deformací.

Inženýrská geodézie se vyznačuje vysokými nároky na přesnost měření a také tím, že měření jsou prováděna ve velmi obtížných podmínkách. Nasazení nejmodernějších přístrojů je často jedinou cestou pro splnění požadavků na přesnost a zároveň umožňuje dodržet bezpečnost práce a výrazně snížit riziko pracovních úrazů. V této souvislosti je třeba zmínit použití družicových navigačních systémů při vytyčování velkých staveb, metodu laserového skenování či metody automatizovaného řízení stavebních strojů. Současný navigační systém NAVSTAR GPS byl již úspěšně použit v některých výše zmíněných aplikacích. Využití systému Galileo by však přineslo zvýšení přesnosti výsledků a tím i nahrazení klasických terestrických metod v aplikacích inženýrské geodézie s vysokými nároky právě na přesnost určení polohy. Ještě důležitější dopad nového systému Galileo by byl v případech, kdy měření jsou vykonávána v nepříznivých podmínkách (např. omezená viditelnost družic způsobená zástavbou atd.) Více než dvojnásobný počet družic (celkem 54 družic při současném použití systému NAVSTAR GPS a Galileo oproti pouhým 24 družicím NAVSTAR GPS) by umožnil vysoce přesná měření i v těchto obtížných podmínkách.

Problematikou geodetických měření na stavbách se zabývá Katedra speciální geodézie Fakulty stavební ČVUT a rovněž Katedra geodézie a pozemkových úprav FSv ČVUT. Doc. Blažek, vedoucí posledně zmiňované katedry, se zabývá měřením deformací mostů optickými metodami. 
Ing. Štroner, PhD z Katedry speciální geodézie FSv ČVUT se zabývá metodou laserového skenování staveb. Doc. Hampacher je odborníkem na matematické zpracování geodetických měření metodami vyrovnávacího počtu.

\section{Stavební mechanika, dopravní stavby, inženýrství životního prostředí, vodní hos- podářství a vodní stavby}

Katedra stavební mechaniky Fakulty stavební ČVUT se mimo jiné dlouhodobě zabývá monitorováním statického a dynamického chování významných stavebních konstrukcí a detekcí jejich nadměrných statických deformací a dynamických výchylek. V současné době je přesnost družicových měření NAVSTAR GPS zpravidla nižší než přesnost požadovaná při výše zmíněném monitorování. Lze však očekávat, že po zvýšení přesnosti zavedením systému Galileo bude v některých případech možné nahradit terestrická měření měřeními družicovými s výraznými ekonomickými úsporami a zvýšením bezpečnosti práce. Pro posouzení získaných výsledků by byla velmi cenná i skutečnost, že opakovaná měření by bylo možno nahradit měřeními permanentních družicových přijímačů a eliminovat tak vliv periodických jevů (např. střídání teplot v průběhu dne či roku) na celkově zjištěné chování stavebních konstrukcí.

Katedra železničních staveb FSv ČVUT se mimo jiné zabývá sledováním posunů vybraných úseků tramvajových a železničních tratí - např. zkušebních úseků s novými konstrukčními prvky. V současné době jsou tyto posuny sledovány terestrickými metodami. Nasazení družicových metod by bylo velmi výhodné jak z ekonomického hlediska, tak z hlediska bezpečnosti práce. Podmínkou je nejen vysoká přesnost měření, ale především schopnost dosáhnout této vysoké přesnosti v poměrech běžných na železničních a tramvajových tratích - omezení viditelnosti družic v zářezech, zhoršení př́ijmu signálů v důsledku vegetace atd.

Katedra zdravotního a ekologického inženýrství FSv ČVUT se zabývá modelováním distribučních sítí a srážkoodtokových procesů v urbanizovaných povodích i hodnocením ekologického stavu vodních toků a vodárenských nádrží, pro něž jsou zapotřebí přesné informace o druhu a velikosti ploch v povodí včetně jejich výškového zaměření a ohraničení a přesné umístění objektů, např. povrchových znaků vodovodů a kanalizací, které by se s výhodou daly získat pomocí družicových metod.

Katedra ocelových a dřevěných konstrukcí FSv ČVUT se podílí na řešení úkolů, které si kladou za cíl sledovat takové ocelové a dřevěné konstrukce, $u$ kterých je riziko nadměrných deformací a posunů. Tato rizika jsou zásadní například pro historicky cenné věžové dřevěné konstrukce střech. U většiny konstrukcí dochází k postupné degradaci materiálu nosné konstrukce a při extrémních klimatických podmínkách (zatížení větrem) hrozí riziko jejich poruch a nenávratných ztrát. Proto je měření navrhovanou metodou při využití milimetrových přesností velmi cenné a může velmi dobře identifikovat poruchu konstrukce. Použití družicových metod u těchto konstrukcí je velice výhodné, nebot se jedná o stavby zpravidla převyšující okolní zástavbu. Proto je jakékoliv jiné měření v takovýchto podmínkách velmi náročné, využití družicových přijímačů je naopak v tomto př́padě velice výhodné nebot nehrozí, že by přijímače byly zastíněné.

Použití navrhované metody by rovněž významně přispělo při měřeních na vysokých stožárech, věžích, komínech a jiných obdobných konstrukcích. U takovýchto staveb je často rozhodující II. mezní stav (mezní stav použitelnosti). Zejména se jedná o dynamické účinky větru, které je nutno sledovat jak ve směru působícího větru, tak v kolmém směru, kde obzvláště válcové stavby mohou být účinkem větru rezonančně rozkmitávány a tím i ohrožovány únavovým 
poškozením. Účinky větru se velmi komplikovaně sledují ve větrných tunelech (používají se zmenšené modely), kde se pouze simulují skutečné účinky větru. Měření pomocí družicových přijímačů by poskytlo velmi ojedinělé informace, na jejichž základě by bylo možné analyzovat skutečné působení větru na skutečných konstrukcích. Pro rozvoj v této oblasti navrhování konstrukcí by měl navrhovaný projekt významný vliv. Katedra geotechniky je připravena k účasti na řešení výzkumného záměru využitím znalostí, týkajících se základových poměrů staveb (stavu horninového prostředí v podzákladí staveb) a jejich základových konstrukcí, včetně geotechnických příčin statických poruch. Tvarové deformace stavebních objektů mohou být vyvolány i dynamikou horninového prostředí, bez přihlédnutí k tomu, zda jde o autonomní projevy v masivu, nebo o interakci masivu se stavbou. Spolehlivé výsledky tedy přinesou zpravidla jen komplexní posouzení. Katedra je materiálně i personálně vybavena ke sledování a hodnocení dynamiky horninového prostředí v interakcí se stavebními objekty. Očekávaným výsledkem spolupráce s ostatními zúčastněnými řešiteli je mj. získání hodnotných geodetických a geotechnických podkladů pro typové hodnocení lokalit; řešitelský kolektiv katedry geotechniky poskytne také inženýrsko-geologické a geotechnické podklady i k ostatním projektovaným pracem.

\section{Dílčí cíle výzkumného záměru}

\section{Systémová analýza a stanovení základních úkolů (SA)}

Proces navazuje na výsledky řešitelů dosažené před započetím projektu. Probíhá na začátku a zároveň po celou dobu trvání projektu, aby byla zajištěna aktuálnost stanovovaných dílčích úkolů v souvislosti s mezinárodním vývojem v dané problematice. Systémové řešení projektu sestává ze základní analýzy řešených problémů, aplikační analýzy a následném stanovení požadavků na funkcionalitu a vlastnosti subsystémů, aby byla zajištěna vzájemná provázanost jednotlivých procesů.

\section{Výzkum, vývoj, testování a optimalizace výpočetních algoritmů zpracování informací z družic Galileo (GA)}

Proces je jedním z hlavních úkolů zamýšleného výzkumného závěru. Navazuje na předchozí práce řešitelů týkající se vývoje programů pro zpracování měření NAVSTAR GPS v reálném čase. V rámci této části výzkumného záměru chceme

- vyvinout program pro zpracování tzv. fázových měření systému Galileo

- posoudit vliv korekcí systému EGNOS na určovanou polohu přijímače, navrhnout optimální způsob využití systému EGNOS pro zamýšlené technické aplikace

- zkoumat problémy vyplývající z kombinace měření NAVSTAR GPS a Galileo (rozdílné referenční systémy atd.) a připravit softwarové nástroje pro řešení těchto problémů

V současné době je připravována nová generace přijímačů družicových signálů. Tyto nové přijímače se od současných liší v tom, že některé hardwarové prvky jsou nahrazovány prvky firmwarovými. Přijímače budou vybaveny výkonnými procesory a stanou se do jisté míry univerzálními. Úpravou či změnou firmwaru bude možno použít přijímač $\mathrm{k}$ měření s různými globálními polohovými systémy či jejich kombinacemi (NAVSTAR GPS, Galileo a případně i další). Přijímače budou mít vlastní operační systém, který umožní spuštění uživatelských 
programů přímo v přijímačích. Otevírá se tak cesta k vývoji nových aplikací, které optimalizují zpracování původních surových dat, řeší komunikaci s ostatními zařízeními v rámci dané technologie atd. Výzkum a vývoj takovýchto aplikací, které jsou na hranici firmwaru a uživatelské aplikace, bude rovněž součástí naší práce.

\section{Integrace polohových geodetických základů do jednotného evropského rámce $(\mathrm{PZ})$}

Cílem je realizace evropského souřadnicového systému ETRF89 na území ČR s centimetrovou přesností a jeho navázání na stávající polohové a výškové souřadnicové systémy (S-JTSK, S42/83, ČSNS) s centimetrovou přesností. Pouze při dodržení tohoto standardu bude možné provádět lokalizaci ve všech souřadnicových systémech s požadovanou přesností. Protože pohyb družic je primárně popisován zákony nebeské mechaniky v nebeském kvazi-inerciálním nebeském systému, bude zapotřebí se věnovat též dalšímu zpřesňování transformačních vztahů mezi tímto nebeským a rotujícím pozemským referenčním systémem (precese, nutace, světový čas, pohyb pólu). Některé z parametrů orientace Země (precese, nutace, světový čas) přitom není možné získat pouze z pozorování družic, je potřeba je dále kombinovat s pozorováním VLBI; výzkum bude proto zaměřen též na techniku těchto kombinací. Pro získání integrovaných polohových základů je nutno mimo jiné provést další zpřesnění průběhu plochy kvazigeoidu na území ČR zpracováním heterogenních dat, provést testování jeho přesnosti metodou "GPS-nivelace", vytvořit algoritmus transformace ETRF89 - S-JTSK, resp. ETRF89 - S42/83 a provést jeho softwarovou realizaci s ohledem na jeho začlenění do GIS softwarů

\section{Aplikace metod moderní numerické matematiky (NM)}

Nalezení efektivních a numericky stabilních metod řešení matematických problémů, které se vyskytují při zpracování měření družicových navigačních systémů a při zpracování velmi rozsáhlých soborů geoinformací. V návrhu výzkumného záměru nelze přesně odhadnout, které matematické problémy se při řešení vyskytnou. Obecně lze očekávat, že bude nutno řešit problémy při řešení velkých soustav lineárních rovnic (při zpracování měření družicových navigačních systémů se mohou vyskytnout soustavy s počtem neznámých v řádu 100 tisíc). Požadavkem řešení je nejen vysoké numerická stabilita, ale i rychlost. Optimalizaci algoritmů lze dosáhnout tím, že využijeme určitých apriorních znalostí o struktuře systémů rovnic (např. jde o tzv. "řídké" systémy rovnic nebo o systémy, v nichž některé neznámé jsou silně závislé atd.) Při zpracování družicových měření v reálném čase se nejčastěji (z důvodů efektivity výpočtu) používají různé modifikace tzv. Kalmanova filtru. Obecně lze říci, že tato filtrace může být numericky velmi nestabilní. Optimalizace filtračních algoritmů z hlediska numerické stability je dalším z úkolů této části projektu.

\section{Monitorování deformací mostních konstrukcí (MK)}

Tuto oblast považujeme za jednu z nejslibnějších aplikací družicových měření ve stavebnictví. Úkolem projektu je ověření využitelnosti nového evropského navigačního systému Galileo pro monitorování statického a dynamického chování stavebních konstrukcí a pro detekci jejich nadměrných statických deformací a dynamických výchylek.

Z hlediska použitelnosti, provozuschopnosti, dlouhodobé spolehlivosti a životnosti předpjatých mostních konstrukcí větších rozpětí je vysoce aktuální otázka trvalého růstu deformací v čase. Společenský význam problémů provozuschopnosti mostů je mimořádný a jejich důsledky vyvolané náklady v ekonomickém pohledu mnohonásobně převyšují náklady vyvolané poruchami 
statického charakteru.

Zkušenosti ukazují na větší hodnoty skutečných průhybů oproti výpočtové predikci a na jejich dlouhodobý nárůst $\mathrm{v}$ čase - skutečné dlouhodobé průhyby jsou větší než průhyby stanovené dosavadními výpočty. Př́čin tohoto jevu je celá řada a je třeba je objektivně analyzovat.

Jedním (nikoliv však jediným) z významných faktorů ovlivňujících vývoj průhybů je dotvarování a diferenční smrštování betonu. Vzhledem k tomu, že jde o velmi složité jevy zahrnující interakci řady faktorů na různých úrovních mikrostruktury, které jsou ovlivňovány mnoha proměnnými účinky, je matematické vyjádření vývoje těchto jevů nutně dosti složité.

Řešitelský tým Katedry betonových konstrukcí a mostů FSv ČVUT již přinesl zcela konkrétní výsledky charakteru jak původních přínosů v oblasti teorie stavebních konstrukcí, tak i podpory pro praktické projektování a sledování vývoje přetvoření velkých mostních staveb. Byly vytvořeny nové matematické modely a metodika výpočtů, zobecněny výsledky a zpracována praktická doporučení která nacházejí uplatnění jakožto účinný nástroj pro spolehlivý a hospodárný návrh konstrukcí, pro dosažení úspor konstrukčních materiálů, energie a finančních nákladů, a to nejen na výstavbu, ale i na údržbu, opravy a rekonstrukce.

Pro kalibraci teoretických predikcí mají informace o skutečném průběhu nárůstu deformací mostních konstrukce $\mathrm{z}$ předpjatého betonu zcela zásadní význam. Lze je využít jak k posuzování stavu sledované mostní konstrukce, tak i k ověření výstižnosti matematických modelů predikce dotvarování.

Příklad: na mostu na dálnici D8 přes Ohři u Doksan je dlouhodobě sledován vývoj průhybů. V nejdelším poli, které měří cca. $130 \mathrm{~m}$, byl za 5 let zjištěn nárůst trvalého průhybu uprostřed rozpětí o cca. $3 \mathrm{~cm}$. Při takto velkých deformacích je možné uvažovat o jejich měření metodami družicové geodézie, u nichž lze očekávat oproti běžným metodám nejen srovnatelnou či vyšší přesnost, ale zejména možnost monitorování v průběhu celého dlouhodobého měření.

Zatížení změnou teploty představuje u významných stavebních konstrukcí podstatnou složku jejich celkového namáhání. Informace o deformacích konstrukce způsobené změnou jejich teploty, které by byly získány pomocí systému Galileo, doplněné o měření změn teploty, které deformace vyvolaly, lze využít $\mathrm{k}$ upřesňování poznatků o podkladech, výpočtových modelech a postupech pro výpočet a posuzování vlivu změn teploty na spolehlivost zkoumaných konstrukcí.

Příklad: v současné době je na několika mostech v ČR soustavně sledována změna jejich teploty za účelem ověření hodnot, které jsou předepsány $\mathrm{v}$ převzaté evropské normě EN 1991-1-5. Katedra stavební mechaniky FSv ČVUT sleduje změny teploty mostu z předpjatého betonu přes Sedlický potok na dálnici D1 v řezu ležícím uprostřed jeho nejdelšího pole, jehož rozpětí je $75 \mathrm{~m}$. Průhyb od změny teploty dosahuje cca. $1 \mathrm{~cm}$.

Z výše uvedených skutečností je zřejmé, že systém Galileo by mohl být použit pro :

- monitorování nárůstu trvalých průhybů významných mostních konstrukcí z předpjatého betonu.

- monitorování nárůstu poddajnosti významných stavebních konstrukcí způsobené postupnou degradací jejich nosné konstrukce. 
- monitorování kvazistatických deformací významných stavebních konstrukcí vyvolaných změnou jejich teploty.

- monitorování změn základních vlastních frekvencí významných stavebních konstrukcí v reálném čase způsobené postupnou degradací jejich nosné konstrukce.

- detekce nadměrných statických deformací sledované konstrukce vlivem extrémního statického nahodilého zatížení (např. sněhem).

- detekce nadměrných dynamických výchylek sledované konstrukce vlivem extrémního dynamického nahodilého zatížení (např. rozkmitání sledované konstrukce extrémními účinky větru, rozkmitání lávky pro pěší vandaly) nebo ztrátou aerodynamické stability.

V první fázi se předpokládá porovnání výsledků měření získaných systémem Galileo s výsledky měření provedeného klasickým způsobem (řešitelské pracoviště: Katedra geodézie a pozemkových úprav FSv ČVUT). Po ověření výsledků by měl být možný přechod od klasických měření $\mathrm{k}$ měření družicovým s výhodami v ekonomičnosti a bezpečnosti práce a spolehlivosti výsledků.

Součástí úkolu je rovněž vývoj metod pro matematicko-statistické zpracování získaných dat a programové zajištění výpočetních prací.

\section{Sledování poruch a nadměrných deformací významných historických pozemních objektů a staveb, sledování výchylek a deformací vysokých stožárů, věží a komínů (HK)}

Cílem této části projektu je ověření využitelnosti nového evropského navigačního systému Galileo pro monitorování statického a dynamického chování významných historických stavebních konstrukcí a pro detekci jejich nadměrných statických deformací a dynamických výchylek, které zpravidla signalizují poruchu v nosné konstrukci.

Rizika poruch a poškození jsou zásadní například pro historicky cenné věžové dřevěné konstrukce střech. U většiny dřevěných konstrukcí dochází k postupné degradaci materiálu nosné konstrukce (působení vlhkosti, dřevokazných škůdců atd.) a při extrémních klimatických podmínkách (u věžových staveb zejména zatížení větrem) hrozí riziko jejich poruch. Proto by bylo využití družicových přijímačů s milimetrovými přesnostmi velmi cenné a může velmi dobře identifikovat poruchu konstrukce a poskytnout odpověd' na otázku, zda je nutné přistoupit k sanaci (zesílení) nosné konstrukce. Použití družicových metod u těchto konstrukcí je velice výhodné, nebot’ se jedná o stavby zpravidla převyšující okolní terén a okolní stavby. Jakékoliv jiné měření je v takovýchto podmínkách velmi náročné a drahé, využití družicových přijímačů se jeví naopak v tomto případě velice výhodné nebot nehrozí, že by přijímače byly zastíněné, není potřeba stálá obsluha, měření lze velmi snadno omezit pouze na určité časové období, ve kterém je konstrukce vystavena extrémním účinkům.

Družicová měření jsou jednou z mála možností, jak ověřit chování vysokých stožárů, věží, komínů a jiných obdobných konstrukcích při působení větru. U těchto staveb je zpravidla rozhodující mezní stav použitelnosti (tzv. II. mezní stav). Jedná se zejména o dynamické účinky větru, které je nutno sledovat jak ve směru působícího větru, tak v kolmém směru, kde obzvláště válcové stavby mohou být účinkem větru rezonančně rozkmitávány a tím i ohrožovány únavovým poškozením. Účinky větru se velmi komplikovaně sledují na zmenšených modelech ve větrných tunelech, kde se simulují skutečné účinky větru. Měření pomocí přijímačů Galileo 
by poskytlo velmi ojedinělé informace, na jejichž základě by bylo možné analyzovat skutečné působení větru na skutečných konstrukcích. Vzhledem k proporcím těchto objektů je jejich poměr výšky a širrky velmi nevýhodný pro ověřování ve větrných tunelech, sledování výše zmíněných veličin na skutečných objektech by znamenalo výrazný posun v poznání v tomto oboru navrhování konstrukcí.

Dalším přínosem by bylo provádění měření na takových konstrukcích, které již nesou poměrně značné množství anténních systémů a u kterých je tendence jejich počty a rozměry dále zvyšovat. S tímto stavem se budeme setkávat stále častěji, nebot’ jde o doprovodný jev spojený s rozvojem komunikačních sítí. Výškových budov a konstrukcí je omezený počet, v zastavěných lokalitách již dále není možné stavět nové výškové stavby a konstrukce a proto dochází $\mathrm{k}$ nárůstům ploch anténních systémů na stávajících konstrukcích. Tento růst má však svoje hranice a rizika z poruch při extrémních povětrnostních podmínkách stoupají. Proto by bylo možné na vybraných konstrukcích nejprve sledovat jejich chování při současném stavu a po té, co se počet či plocha anténních systémů navýší. Při významném nárůstu deformací bude možné rozhodnout, zda technologie neohrožuje bezpečnost a stabilitu konstrukce a popř́padě jak velké přitížení od vodorovných zatížení bude ještě pro konstrukci přípustné z hlediska zachování spolehlivosti celého systému.

\section{Aplikace systému Galileo v krajinném a vodohospodářském inženýrství (VI)}

Řešitelská pracoviště (Katedra hydromeliorací a krajinného inženýrství Fsv ČVUT a Katedra zdravotního a ekologického inženýrství) se budou zabývat vývojem expertních a varovných systémů pracujících pro podporu rozhodování v reálném čase. Půjde především o následující oblasti:

- vodní hospodářství - sledování kritických situací jako jsou havárie, povodně, apod.

- krajinné inženýrství - mapování cenných prvků v krajině a jejich sledování, ochrana př́rody a krajiny

- doprava a její dopad na životní prostředí

Přesná měření pomocí systému Galileo budou sloužit ke zpřesňování polohových a výškových informací povrchových znaků a $\mathrm{k}$ přesnému umístění dat dálkového průzkumu Země. Možné aplikace jsou např. v následujících oblastech:

- přesné vytyčení povrchových znaků vodovodů a kanalizací v souřadnicích x,y,z umožňující rychlý př́ístup k ovládacím prvkům a šachtám pro účely provozu a rychlého zásahu při haváriích (digitalizace mapových podkladů neposkytuje výškovou souřadnici, geodetická měření jsou náročná a nákladná, prvky jsou často obtížně přístupné, zejména kvưli husté dopravě)

- informace pro srážkoodtokové modely kvantity a kvality vody (typy a velikosti ploch v území, jejich sklony),

- podklady pro hodnocení ekologického stavu vodních toků a vodárenských nádrží (jejich zaměření, sledování změn koryt, pobřežních zón a pokryvu povodí, kolísání hladin),

- sledování havárií ovlivňujících vodní zdroje, postup eutrofizace nádrží,

- sledování poklesů inženýrských sítí v důsledku poklesu povrchu důlní činností, apod. 
Z obou řešitelských pracovišt se předpokládají jednak výstupy v teoretické rovině - studie proveditelnosti, návrhy aplikací a posouzení technických nároků systému a ve spolupráci s ostatními pracovními skupinami definování nutných technických požadavků na systém, jednak výstupu v formě demonstrace jednotlivých aplikací

\section{Aplikace systému Galileo v silničním stavitelství (SI)}

Přesná lokace v čase a místě se stává nezbytnou součástí silniční dopravy a silničního stavitelství. Aplikace existují např. v řízení a regulaci nákladních vozidel, snadnějších kontrolách při přetížení, zpoplatnění dálničních a rychlostních komunikací atd. Jedním z důležitých úkolů je sledování přetížených vozidel a nadměrných a nebezpečných nákladů během přepravy. Nový systém Galileo se též jeví výhodný pro řešení problematiky oprav a údržby vozovek. Jde např. o optimalizaci odstraňování sněhu v zimních měsících, diagnostiku aktuálního stavu a poruch vozovek, včetně měření jejich proměnných a neproměnných parametrů.

Řešitelské pracoviště (Katedra silničních staveb FSv ČVUT) se bude zabývat vývojem expertního systému, který by komplexně řešil výše uvedenou problematiku s využitím sytému Galileo jako základního zdroje prostorových dat. Pozornost bude věnována probíhajícím projektům GPS v Kanadě a jihovýchodní Asii. Systém Fsv však bude využívat i ty vlastnosti nových navigačních systémů, kterými se tyto liší od systémů stávajících. Jde především o možnost komunikace mezi uživatelem (např. vozidlem) při zjištění krizové situace a expertním systémem zajištujujím reakci na vzniklou situaci.

\section{Aplikace systému Galileo v železničním stavitelství (ŽS)}

Řešitelské pracoviště (Katedra železničních staveb FSv ČVUT) se bude zabývat vývojem aplikací systému Galileo pro dlouhodobé sledování prostorových posunů vybraných úseků tramvajových a železničních tratí. Půjde v tomto případě o nahrazení technologií založených na terestrických měřeních technologií založenou na měřeních družicových s výhodou vyšší ekonomičnosti a bezpečnosti práce. Sledování posunů tratí je nezbytné v př́ípadech, kdy jde o tratě s novými konstrukčními prvky, vysokorychlostní tratě a tratě ohrožené např. svahovými pohyby v důsledku lidské činnosti (tzv. technogenní pohyby např. v důsledku poddolování apod.) Cílem automatického sledování je zajištění vyšší bezpečnosti provozu kolejových vozidel.

\section{Kombinace metody laserového skenování a systému Galileo (LS)}

Rešitelské pracoviště (Katedra speciální geodézie FSv ČVUT) se zabývá metodami sledování a dokumentace staveb tzv. laserovými skenery. Jde o velmi efektivní a moderní metodu, která umožňuje hromadný sběr prostorových dat a jejich následné počítačové zpracování a vizualizaci. Nejdůležitější použitý přístroj - laserový skener - pracuje v lokálním souřadném systému a výsledky měření je třeba transformovat do souřadnicového systému mapového podkladu, národního referenčního systému nebo obecně do zvoleného dobře definovaného systému souřadnic. Pro efektivní a přesné provedení této transformace se jeví jako velmi vhodné vyvinout technologie kombinace laserového skenování s určováním polohy opěrných bodů metodami družicové geodézie s využitím systému Galileo. Navržený úkol by zahrnoval

- výzkum možností sběru dat laserovými skenery pro dokumentaci staveb,

- výzkum možností sběru dat laserovými skenery pro analýzu změn stavebních konstrukcí a dalších objektů, 
- zpracování, vizualizace a prezentace dat pořízených laserovými skenery,

- výzkum možností propojení měření laserovými skenery s družicovými daty systému Galileo,

- porovnání a skloubení terestrických geodetických technologií a moderních navigačních metod se zaměřením na evropský navigační systém Galileo,

- výzkum možností získávání podkladů pro rozhodování podnikového facility managementu,

- využití získaných 3D modelů v městských informačních systémech (MIS)

\section{Aplikace systému Galileo v experimentální geotechnice (EG)}

Při geotechnickém průzkumu je posuzován stav horninového či zeminového prostředí a jeho možný vliv na stavbu, nebo na již existující objekty. Častým úkolem je vyhledávání diskontinuit, oslabených zón, dutin a dalších podzemních nehomogenit. To vše poskytuje průzkum pomocí georadaru, nejlépe v kombinaci s dalšími metodami (mělkou refrakční seismikou, mikrogravimetrií).

Využití georadaru umožňuje získat neocenitelné informace o geologické stavbě v okolí trasy stavby, jako např. o hloubce a reliéfu skalního podloží, litologických změnách, výskytu poruchových zón apod. Umožňuje lokalizaci inženýrských sítí a podzemních objektů. Na základě výsledků průzkumu pomocí georadaru lze optimalizovat trasu stavby, zatřídit zemní práce, stanovit nejvhodnější technologii, stanovit rozsah trhacích prací, posoudit stabilitu území či případný vliv stavby na okolí. Georadar má své uplatnění jak během výstavby tak po jejím skončení (např. při posuzování kvality zhutnění). Nespornou výhodou je získání vysoké hustoty měřených dat. Zatímco vzdálenost mezi průzkumnými vrty činí často několik set metrů, krok měření při použití georadaru se pohybuje v řádu decimetrů.

Využití georadaru ve spojení se systémem Galileo umožní získávat přesně lokalizované výstupy tohoto průzkumu navázáním na souřadný systém. Bude možné vytvořit 3D automatizovanou kontinuální databázi podloží rozsáhlých území spojením nedestruktivního způsobu geotechnického průzkumu se systémem Galileo.

\section{Hodnocení rizika přetvoření ve spolupůsobení stavební konstrukce a horni- nového masívu (GT)}

Cílem této části projektu je sledování historických staveb (hrady, zámky - Kunětická hora, Valdštejn), skládek, výsypek (Palivový kombinát Ústí nad Labem - Rabenov), hald, poddolovaných území (vědecko výzkumná podzemní laboratoř, štola Josef, Mokrsko), svahových deformací (Čertovka - Ústí n.L., Vaňov), popřípadě dopravních staveb (dálniční stavby), hydrotechnických (sypané hráze apod.), průmyslových staveb a inženýrských konstrukcí (mosty) z hlediska přírodních a antropogenních deformací horninového masívu. Po archívní studii, by byly vybrány citlivé lokality z hlediska existujících pohybů (svahové deformace, eroze, povodňové transporty a akumulace, senzitivní zeminy, lidský zásah). Po zúžení výběru na počet objektů, který je ve výzkumném záměru časově a personálně zpracovatelný, budou osazeny měřičské prvky a bude prováděno režimní sledování, které bude vztaženo $\mathrm{k}$ měřením prováděným na horninovém masívu, př́ípadně v podzemí a ve vrtech. Závěrem a výsledkem bude hodnocení možnosti podobných měření a sledování na stavebních objektech. 


\section{Vývoj webových služeb pro geoinformatiku (WS)}

Cílem procesu je vývoj obecného objektového systému pro geoinformatiku s cílem sjednotit rozličné geoinformační služby tak, aby přístup k nim byl homogenní. Rozhraní každé služby bude popsáno pomocí XML v jazyce WSDL. Pro uživatele s registrovaným účtem bude možné přistupovat $\mathrm{k}$ výsledkům zadaných úloh, vlastní geoinformační systém bude napsán $\mathrm{v}$ jazyce Java s využitím servletů a databázového ovladače JDBC. Oprávnění uživatelé budou moci registrovat v systému vlastní úlohy.

\section{Referencování státních mapových děl velkých a středních měřítek pomocí systému Galileo (MA)}

Využití měření družicového navigačního systému je nemyslitelné bez začlenění výsledků do stávajících mapových podkladů. Na území ČR se vyskytuje řada státních mapových děl celkem ve čtyřech souřadnicových systémech a třech kartografických projekcích, s neobyčejně pestrou paletou systémů kladu a značení mapových listů. Pro potřebu digitální kartografie, výměnu kartografických dat se zahraničím a obecně všechny moderní technické aplikace je třeba zavést bezešvé mapy (tj. mapa jako celek nikoli soubor mapových listů) v zobrazení a souřadnicovém systému podle volby uživatele. Problémy vznikají např. proto, že podkladové mapy jsou získány skenováním a sousedící listy nemají vyrovnané styky a navíc mají nepravidelnou srážku. Řešitelské pracoviště (Katedra mapování a kartografie FSv ČVUT) se bude zabývat vývojem nástrojů pro převod existujících mapových podkladů do jednotného (elektronického) formátu tak, aby je bylo možno používat společně s družicovým navigačním systémem Galileo.

\section{Aplikace systému Galileo pro zvýšení efektivity vedení katastru nemovitostí $(\mathrm{KN})$}

Technické aplikace navigačního sytému ve stavebním inženýrství závisí na bezchybné funkci nového Informačního systému katastru nemovitostí (ISKN), a na rychlém poskytování aktuálních dat pro jeho grafickou část (SGI). V této souvislosti bude řešena problematika tvorby rychlých výstupů v podobě tématických map pro krizový management v době živelních katastrof nebo obdobných situací. Lokalizaci vybraných prvků v území pomocí systému GALILEO bude možno vhodně kombinovat s obrazovými daty (barevná ortofota) určenými pro zjištování a sledování využívání pozemků systémem IACS, podle požadavků a pravidel EU pro poskytování dotací pro zemědělskou výrobu.

\section{Využití systému Galileo ve fotogrammetrii (FG)}

Laboratoř fotogrammetrie se zabývá řadou úkolů, které jsou vázány na přesné určení polohy.

Činnost laboratoře je dlouhodobě zaměřena na dokumentaci a prezentaci památkových objektů s cílem vytvoření rozsáhlé virtuální databáze památkových objektů v prostředí sítě Internet. První úspěšné pokusy v této oblasti byly již u nás provedeny http://lfgm.fsv.cvut.cz, funkční je prototyp databáze malých památkových objektů PhotoPa. Ten by měl být doplněn zejména o možnosti animací a virtuálních rekonstrukcí objektů a měl by být zpřistupněn do formy zjednodušené databáze široké veřejnosti pro virtuální prohlídky a turistiku. Vzhledem k ukládání rozsáhlého množství dat do prostředí GIS a jejich lokalizovatelnost je nutno pro každý objekt určit definiční bod nebo body. Dosud jsme používali pro tuto činnost odměření polohy z podrobné mapy nebo turistickou GPS. Dalším předpokládaným stupněm systému bude vizualizace objektu na základě jeho polohy v mapě. Zde je možnost systému Galileo ve 
spojení s digitální mapou. Obdobný přístup lze využít při dlouhodobém průzkumu geoglyfů a petroglyfů v Perú, který ve spolupráci s HTW Dresden a INC Peru probíhá již několik let. Zde jde o využití metod přesných GPS pro dokumentační práce v extrémních podmínkách pouště a vysokých hor. Další výzkumná činnost předpokládá vytvoření systému pro víceúčelovou navigace po kulturních památkách. Zde by bylo možno použít digitální mapový podklad a doplnit ho dalšími užitečnými informacemi. Laserové skenování se stalo v posledních několika letech novou technologií dokumentace a hromadného sběru třírozměrných bodů z okolí. Zároveň se objevily také dynamické metody, využívající systému GPS doplněného inerciálním navigačním systémem. Systémy s inerciální jednotkou patří dnes ke špičkovým technickým zařízením a využívají se v leteckých aplikacích. Pozemní dynamické systémy jsou zatím ve vývoji. Cílem výzkumu v tomto případě bude vytvoření dynamického systému pro zaměřování pozemních liniových oblastí umístěný na automobilu nebo železničním vozidle. Jádrem systému bude přijímač Galileo a laserová měřící hlava. Předpokládaným výsledkem měření by byl 3D model blízkého okolí projížděného úseku s víceúčelovým využitím. 